\title{
Examination of Professional Commitment Level of Social Workers According to Some Variables
}

\author{
Sosyal Hizmet Uzmanlarının Mesleki Bağl1lık Düzeylerinin Bazı \\ Değişkenlere Göre İncelenmesi
}

Semra Saruç*1, Hüsnünur Aslantürk ${ }^{2}$

\begin{abstract}
Objective: This study was conducted to examine work commitment of social workers up to some variables such as gender, age, income level, marital status, working time/duration etc. Method: Study was executed with 153 social workers via relational screening model. Personal information form and Professional Commitment Scale developed by Meyer, Allen and Smith (1993) were used in the study. Findings: Up to the research results; meaningful differences were found within the sub-dimension of professional commitment scale such as emotional commitment and professional commitment permanency with social workers' income $(\mathrm{p}<0,05)$. Social workers with lower income than 3000 TL have lower affective professional commitment and continuous professional commitment. In another word, the more social workers' income level arises, affective-professional commitment and continuous professional commitment level increases. According to the variable of organization, there is a meaningful difference found in continuous professional commitment. Therefore, continuous professional commitment of social workers who are working at Ministry of Health were found lower than the participants working for other institutions within the scope of study. Conclusion: According to the results of the study, the professional commitment of the social workers differ according to variable of the income and the institution they work. There was no statistically significant relationship between gender, age, marital status, educational status, service years variables of employment and professional commitment of social workers.
\end{abstract}

Key Word: Professional commitment, social work, social worker

\section{ÖZET}

Amaç: Bu araştırma, sosyal hizmet uzmanlarının mesleki bağllıklarını çeşitli değişkenler açısından (cinsiyet, yaş, gelir durumu, medeni durum, çalışma süresi vb.) incelemek amacıyla yapılmıştır. Yöntem: İlişkisel tarama modelinde planlanan çalışma 153 sosyal hizmet uzmanı ile gerçekleştirilmiştir. Çalışmada kişisel bilgi formu ve Meyer, Allen ve Smith (1993) tarafından geliştirilmiş olan Mesleki Bağlllık Ölçeği kullanılmıştır. Bulgular: Araştırma sonucunda; sosyal hizmet uzmanlarının gelirleri ile mesleki bağlılık ölçeğinin duygusal mesleki bağlılık ve mesleki devamlılık bağl1lığı alt boyutunda anlamlı farklılık bulunmuştur ( $<<0,05)$. Geliri 3000 TL'nin altında olan sosyal hizmet uzmanlarının duygusal mesleki bağl1lı̆ bağlılığı daha düşüktür. Bir başka deyişle sosyal hizmet uzmanlarının aylık geliri arttıkça duygusal mesleki bağlılıkları ve mesleki devamlılık bağlılı̆̆ı artmaktadır. Sosyal hizmet uzmanlarının çalıştıkları kuruluş değişkenine göre mesleki devamlılık bağlılığında anlamlı bir farklılaşma bulunmuştur. Buna göre araştırma kapsamındaki sosyal hizmet uzmanlarından Sağlık Bakanlığında çalışanların mesleki devamlılık bağlılığı diğer kuruluşlarda çalışanlara göre daha düşüktür. Sonuç: Çalışmanın sonuçlarına göre sosyal hizmet uzmanlarının mesleki bağllıklarının gelir durumu, çalıştıkları kurum değişkenine göre farklılaştı̆̆ı görülmüştür. Cinsiyet, yaş, medeni durum, eğitim durumu, çalıştıkları hizmet yılı değişkenleri ile sosyal hizmet uzmanlarının mesleki bağlılığı arasında istatistiksel olarak anlamlı bir ilişki bulunmadığı sonucuna ulaşılmıştır.

Anahtar kelimeler: Mesleki bağlılık, sosyal hizmet, sosyal hizmet uzmanı

Received / Geliş tarihi: 13.10.2017, Accepted / Kabul tarihi: 25.12.2017

${ }^{1}$ Anadolu Üniversitesi Sağlık Bilimleri Fakültesi Sosyal Hizmet Bölümü

*Address for Correspondence / Yazışma Adresi: Doç.Dr. Semra Saruç, Anadolu Üniversitesi Sağlık Bilimleri Fakültesi Sosyal Hizmet Bölümü. Eskişehir-TÜRKIYE. E-mail: semrasaruc@gmail.com

${ }^{2}$ Kocaeli Üniversitesi Sağlık Bilimleri Fakültesi Sosyal Hizmet Bölümü

Saruç S, Aslantürk H. Sosyal Hizmet Uzmanlarının Mesleki Bağlılık Düzeylerinin Bazı Değişkenlere Göre İncelenmesi. TJFMPC, 2018 ;12(1): 24-34.

DOI: $10.21763 /$ tjfmpc.399922 


\section{GíRiș}

"Bireyi uygulamaya bağlayan bir güç"1 olarak tanımlanan bağlılık son elli yıldır literatürde ve iş çevrelerinde önem kazanmış bir kavram olarak karşımıza çıkmaktadır.

Mesleki bağlılık kavramını ilk olarak Greenhaus'un kavramsallaştırdığ 1 bilinmektedir. ${ }^{2}$ Ancak daha sonraları kavram üzerinde çalışan öncüler tarafından farklı şekillerde ele alınmıştır. Literatür incelendiğinde mesleki bağlılığ 1 tek boyutlu ele alan yazarlarla ${ }^{2-4}$ çok boyutlu ele alan yazarlar ${ }^{5,6}$ olduğu görülmektedir.

Mesleki bağlılık kavramı, mesleki kimliğin ön plana çıkarılması, mensubu olunan meslek için çaba sarf edilmesi, mesleki hedef, değer, norm ve etik ilkelere bağlılık geliştirilmesi olarak tanımlanmaktadır. ${ }^{7}$

Blau, (1985) mesleki bağlılığ1, bireyin mesleğine karşı tutum ve davranış biçimi ve buna verdiği çabalar olarak tanımlamıştır. ${ }^{3}$ Meyer ve Allen ise (1991) mesleki bağlllıkla ilgili literatürde oldukça ilgi gören ve bu çalışmanın yöntem kısmında da kullanılan Üç Boyutlu Örgütsel Bağlılık modelini geliştirmiştir. ${ }^{6}$ Aynı zamanda "Üç Bileşen Modeli" olarak da tanımlanan bu modele göre bağlılık, çalışanların örgütle olan ilişkilerini ortaya koyan psikolojik bir durum olarak görülmekte ve o örgütte çalışmaya devam edip etmeme konusunda etkili olmaktadır. Meyer ve Allen mesleki bağlılığı, duygusal, devamlılık ve normatif olarak üç boyutlu olarak kavramsallaştırmıştır. Buna göre her bağlılık boyutunun "bireyin meslekte kalma olasılığı" ile ilişsili olduğu savunulmaktadır.

Duygusal bağlllık, çalışanların kendilerini çalıştıkları kuruma ne kadar özdeşleştirdikleri ile ilgili duyguları ve bireylerin çalıştıkları işyerine olan ilgilerini göstermektedir. Buna göre duygusal olarak mesleğine bağlı bireyler meslekte kalmayı güçlü bir şekilde arzu etmektedir. ${ }^{5}$

Devam ba $\breve{g} l ı l ı \breve{g l}$, bireylerin çalıştıkları işyerlerinden ayrılmaları halinde ortaya çıkabilecek olan maliyetlerin farkındalıkları ile ilgilidir. Bir başka ifadeyle birey birtakım zorunluluklar nedeniyle mesleğinde kalmaya devam etmektedir. ${ }^{5}$ Meyer ve Allen'in modelinin son boyutu ise normatif bağlılıktır. Buna göre bireyler ahlaki bir görev duygusuyla meslekte kalmayı bir sorumluluk olarak görmektedirler. ${ }^{5}$ İleri derecedeki mesleki bağlılık eğitimsel amaçları başarmaya, yeni roller öğrenip mesleki kimliği geliştirmeye yardımcı olur. Mesleki bağlılık aynı zamanda organizasyona yönelik başarıya, rollerin işlevselliğine ve işyerinde kalınıp kalınmayacağına dair eğilimlere etki eder.
"Sosyal değişim ve gelişim, sosyal tutarlılık ve insanların güçlendirilmesi ve özgürleştirilmesi için çalışan akademik bir disiplin ve uygulamaya dayalı bir meslek" olarak tanımlanan ${ }^{8}$ sosyal hizmetin profesyonel bir meslek olarak gelişmesi İkinci Dünya Savaşı sonrasında sosyal devlete ilişkin genel bir anlayışın oluşma süreci ile doğrudan ilişkilidir. Sosyal devletin kurumsallaşması, sosyal hizmetler alanında devlete önemli görev ve sorumluluklar yüklemiş ve sosyal hizmetin bir meslek olarak gelişmesine neden olmuştur. ${ }^{9}$ Türkiye'de 1960'lı yıllardan beri var olan sosyal hizmet mesleğinin gelişimi sosyal hizmetin amaçlarıyla doğrudan ilişkilidir. Ulusal Sosyal Hizmet Uzmanları Derneği sosyal hizmetin amaçlarını genel olarak "insanların sorun çözmek, baş etmek ve gelişimsel kapasitelerini artırmak; insanları kaynak ve olanak sağlayan sistemlerle bağlantılandırmak; sistemlerin etkili ve insancıl olarak işlev görmesini sağlamak ve sosyal politikaların gelişimi ve ilerlemesi için katkıda bulunmak" olarak sıralamıştır. ${ }^{8}$

Sosyal hizmet mesleğinde bağlılık kavramı incelendiğinde mesleki bağlilığın sosyal hizmette yaşamsal önemde olduğu görülmektedir. Çünkü sosyal hizmet ötekine ilgi ya da ötekine yardım etme arzusu etrafinda şekillenmektedir. ${ }^{10} \mathrm{Bu}$ çerçevede bağlılık eğitim ve uygulama süreciyle başlamaktadır. Hizmet verilen grupların hastalar, engelliler, yaşlılar, hükümlüler, çocuklar, kadınlar gibi genel olarak dezavantajlı olarak değerlendirilen gruplardan oluşması, sosyal hizmet mesleğinin uygulama boyutunda mesleki bağlılığ daha önemli ve öncelikli bir konuma taşımaktadır. Ancak mesleğine karşı bağlılığı olan sosyal hizmet uzmanı, çoğu zaman mevzuatta yer alan görev tanımının ötesine taşıyarak başvuranlarının yararı için uygulamalarını gerçekleştirebilmektedir. Sosyal hizmette bağlılığın önemli olmasının bir başka nedeni mesleğe, kuruma ve hizmet alanlara derin bir bağlanma içermesidir.

Mesleki bağlılık, mesleki değerleri yansıtan etik kodlara bağlılık ve bunların yürütülmesi, mesleki kimlik taşıyan ve paylaşan topluluk içindeki bireylerle birlikte mesleki kariyer ve kimliğin sürdürülmesi, bunun yanı sıra ise kısmi otonomi veya özerklik vurgusu taşımaktadır. Bu özelliklerin tümü ise sosyal hizmet disipliniyle yakından ilişkilidir. ${ }^{11}$ Buna göre ileri derecede bağlılık gösteren meslek elemanı, seçmiş olduğu alana kişisel olarak fazlaca odaklanma ve yatırım yapma konusunda isteklidir. ${ }^{11}$

Sosyal hizmet uzmanlarının bağlılığ üzerinde çalışan Banks, mesleki bağlılığın sosyal hizmet uzmanlarının içinde bulunduğu kimlikleri, güdüleri ve ilgileri çerçevesinde şekillenen ilişkileri 
tarafından belirlendiğine dikkat çekmiştir. ${ }^{12} \mathrm{Bu}$ noktada bireyin bireysel özelliklerinin ön plana çıktığı, mesleki eğitim ve uygulama süreciyle şekillenen güdülerin, ilişkilerin, mesleki bağlılığ1 belirlemede önemli bir yeri olduğu görülmektedir. Nihayetinde bireyin mesleği kimliğinin önemli bir parçası haline gelmekte, çevresiyle kurduğu ilişkilerde de belirleyici bir özellik taşımaktadır.

Görüldüğü gibi her meslekte olduğu gibi sosyal hizmet mesleğinde de bağlılık gerek çalışılan grubun incinebilir olması gerekse sosyal hizmet mesleğinin bileşenleri açısından önemli bir unsur olarak öne çıkmaktadır. Bu bağlamda bu çalışmada sosyal hizmet eğitimi almış ve sosyal hizmet uzmanı olarak alanda çalışan kişilerin, mesleki bağlılık düzeylerini bazı değişkenlere (cinsiyet, yaş, gelir durumu vs.) göre incelemek amaçlanmıştır.

\section{YÖNTEM}

Araştırma genel tarama modelinin bir türü olan ilişkisel tarama modeli ile tasarlanmıştır. Karasar ilişkisel tarama modelini, "iki ya da daha fazla değişken arasında birlikte değişim varlığını ve/veya derecesini belirlemeyi amaçlayan araştırma modeli" olarak tanımlamaktadır. ${ }^{13}$ Araştırmada sosyal hizmet uzmanlarının mesleki bağlllık düzeylerinin cinsiyet, yaş, gelir durumu gibi bazı değişkenlere göre incelenmesi amaçlandığından ilişkisel tarama modeli kullanılmıştır.

\section{Evren ve Örneklem}

Araştırmanın evrenini Türkiye genelinde çeşitli kurumlarda çalışan sosyal hizmet uzmanları oluşturmaktadır. Sosyal Hizmet Uzmanları Derneği tarafindan 2015 y1lında derlenen verilere göre Türkiye genelinde dört yıllık sosyal hizmet bölümlerinden mezun olan sayısı 6150'dir. Kamu kurumlarında sosyal hizmet uzmanı/sosyal çalışmacı olarak görev yapan kişi sayısı 4625'tir. Özel kuruluşlarda ve sivil toplum örgütlerinde görev yapan tahmini 350 kişi bulunmaktadır. Kamu kuruluşları içinde sosyal hizmet istihdamına bakıldığında, Aile ve Sosyal Politikalar Bakanlığı ve bağlı kuruluşlarda 2381, Sağlık Bakanlığı ve Bağlı kuruluşlarda 938, Adalet Bakanlığı ve bağlı kuruluşlarda ise 449 sosyal hizmet uzmanının görev yaptığı belirtilmektedir. Diğer kamu kuruluşlarında ise tahmini olarak 840 sosyal hizmet uzmanının çalıştı̆̆ ifade edilmektedir.

Veriler olasılıksız örnekleme türlerinden kolay ulaşılabilir örnekleme yöntemi ile toplanmıştır. Kolay ulaşılabilir örnekleme, örneklemi oluşturmak için en uygun, en ulaşılabilir öğeleri seçmektir. Ulaşılabilir olma coğrafi yakınlığa, erişim kolaylığına veya bir konferansta bulunma gibi firsatlara dayalı olabilir. ${ }^{14}$ Öncelikle veri toplama araçları farklı illerdeki (Ankara, Eskişehir, İzmir, Yalova, Antalya, Konya) belirli sosyal hizmet uzmanlarına e-posta yoluyla gönderilmiş ve kendi kurumlarındaki sosyal hizmet uzmanlarına da iletmeleri istenmiştir. E-mail yoluyla 153 sosyal hizmet uzmanına ulaşılmıştır. Verilerin toplanma süreci 2016 Temmuz-Aralık ayları arasındaki altı aylı dönemde gerçekleştirilmiştir.

\section{Veri Toplama Araçları}

Çalışmada kişisel bilgi formu ve Mesleki Bağlılık Ölçeği kullanılmıştır. Kişisel bilgi formu, sosyal hizmet uzmanları ile ilgili birtakım değişkenler hakkında bilgi toplamak amacıyla araştırmacilar tarafından geliştirilmiştir. Kişisel bilgi formunda sosyal hizmet uzmanlarının cinsiyeti, yaşı, aylık geliri, medeni durumu, eğitim durumu, çalışma yılı, çalıştığ1 kuruluş, çalıştı̆̆ 1 birim ve bu birimdeki çalışma yılı gibi sorular bulunmaktadır.

Mesleki Bağl1lık Ölçeği, Meyer, Allen ve Smith (1993) tarafından geliştirilmiştir. Ölçek, mesleki bağlılığ duygusal mesleki bağlılık, mesleki devamlılık bağl1lığ 1 ve normatif mesleki bağlılık olarak üç boyutlu olarak ele almıştır. ${ }^{5}$

Duygusal mesleki bağlılık, mesleği severek yapma, onunla özdeşleşmiş olmayı ve meslekte kalmayı istemeyi ifade etmektedir. Buna göre mesleğine duygusal olarak bağlı bireylerin meslekte kalmayı çok güçlü bir biçimde arzu etmesi söz konusudur.5 $\mathrm{Bu}$ bağlılığa sahip birey, mesleğinde ilerleme ve kendini geliştirme şansı da yakalamaktadır. ${ }^{15}$

Mesleki Devamlılık Bağlılığı, bireylerin mesleğinden ayrılmasının maliyetini ya da meslekte kalmasından doğacak faydayı dikkate alarak bağlılık geliştirmesi olarak tanımlanmaktadır. ${ }^{5}$ Birey burada mesleğinden ayrılması ile kalmasının maliyet analizini yaparak mesleğinde kalmaya karar verir. Bir başka ifadeyle "mesleğe devam etme isteği" o konuya vazgeçemeyecek kadar yatırım yapmış olmak ve vazgeçmenin yüksek maliyeti ile ilgilidir. ${ }^{16}$

Mesleki bağlılık ölçeğinin son boyutu olarak kavramsallaştırılan normatif mesleki bağl1lık ise bireyin meslekte kalmayı bir yükümlülük ya da sorumluluk hissi olarak görmesi olarak tanımlanmaktadır. Buna göre bireyler belirli bir davranış şeklini benimsemeye ilişkin normatif baskıları içselleştirdiklerinde ve bunun sonucunda fayda gördüklerinde mesleklerine normatif nitelikte bir bağlılık geliştirmektedirler. ${ }^{5}$

Ölçek 18 maddeden ve üç alt boyuttan oluşmaktadır. İlk 6 soru Duygusal Mesleki Bağlılık 
alt boyutunu, 7-12. sorular "Mesleki Devamlılık Bağlılığı" alt boyutunu, 13-18. sorular Normatif Mesleki Bağlılık alt boyutunu oluşturmaktadır. Ölçek özelliği itibariyle 7'li likert tipi bir ölçektir.

Ölçeğin geçerlik ve güvenirliği çeşitli çalışmalarla sınanmış ve yapılan çalışmalar ölçeğin geçerlik ve güvenilirliğini desteklemiştir., ${ }^{5,17-19}$ Ölçeğin özgün çalışmasında örneklem grubu hemşirelerden ve hemşire öğrencilerinden oluşmaktadır. ${ }^{5}$

Literatürde Meyer ve arkadaşlarının geliştirdiği üç boyutlu mesleki bağlılık ölçeğini kullanan Türkçe çalışmalar oldukça sınırlıdır. 11$12,20-22$

Ölçeğin Türkçe güvenirlik ve geçerlik çalışması ilk olarak Baysal ve Paksoy (1999) tarafindan İstanbul'da beş devlet üniversitesinden değişik uzmanlık dallarında görev yapan öğretim üyeleri ile gerçekleştirilmiştir. ${ }^{16} \mathrm{Bu}$ çalışmanın güvenirlik analizinde Cronbach alpha katsayısı 0.7467 olarak bulunmuştur. Ölçeğin güvenirlik ve geçerliği ile ilgili bir başka çalışma Tak ve Çiftçioğlu (2009) tarafından bir üniversite hastanesinde görev yapan 425 hemşire ile gerçekleştirilmiştir. ${ }^{15}$

Bu çalışmada ise örneklem grubu olarak hemşirelerden farklı bir meslek grubu seçildiği için "hemşirelik mesleği/hemşire olmak" gibi ifadeler sosyal hizmet mesleğine uyarlanmış ve bu ifadeler "sosyal hizmet mesleği/sosyal hizmet uzmanı olmak" şeklinde uyarlanmıştır. Meslek grubu ile ilgili ifadelerin değiştirilme konusu ölçeği uyarlayan yazarlara sorulmuş ve onay alınmıştır. Ölçeğin sosyal hizmet uzmanlarından oluşan bir örneklem grubuna uygulanıp uygulanmayacağı ile ilgili güvenirlik testi yapılmış ve Cronbach Alpha değeri 0,81 çıkmıştır. Literatür 0,60 'ın üzerinde çıkan değerlerin kullanılan örneklem grubu için güvenilir olduğunu söylemektedir. ${ }^{23}$

\section{Verilerin Analizi}

Verilerin analizinde IBM SPSS 20 istatistik paket programı kullanılmıştır. Verilerin istatistikî değerlendirmesinde normal dağılıma uygun olup olmadığı ile ilgili Kolmogorov Smirnov testi ve skewness-kurtosis değerlerine bakılmıştır. Veriler normal dağılım gösterdiği için, bağımsız gruplar $\mathrm{t}$ testi ve varyans analizleri yapılmıștır. Yapılan varyans analizi sonucunda farklı olan grupların kaynağını bulmak için de Tukey testi yapılmıştır. Ayrıca verilerden aylık gelir, yaş ve çalışılan süre bağımsız değişkenlerinin duygusal mesleki bağlılık, mesleki devamlılık bağlılığı, normatif mesleki bağlılık bağımlı değişkenleri arasındaki ilişkiler Pearson Momentler Korelasyon analizi (korelasyon anlamlılık seviyesi 0,01) tekniği kullanılarak hesaplanmıştır.

\section{BULGULAR}

Araştırma kapsamındaki katılımcıların çeşitli demografik özellikleri tablo 1 'de verilmiştir. Buna göre sosyal hizmet uzmanlarının \%62,1'i kadın, \%72,5'i evli, \%77,8'inin lisans mezunu olduğu görülmektedir. Sosyal hizmet uzmanlarının yaş

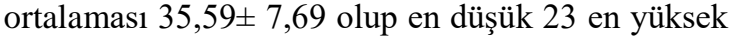
57 'dir. Sosyal hizmet uzmanlarının ortalama geliri $3174,82 \pm 538,46$ olup en düşük 1750 en yüksek 6000 'dir.

Tablo 1. Katılımcıların tanımlayıcı özelliklerine göre dağılımı

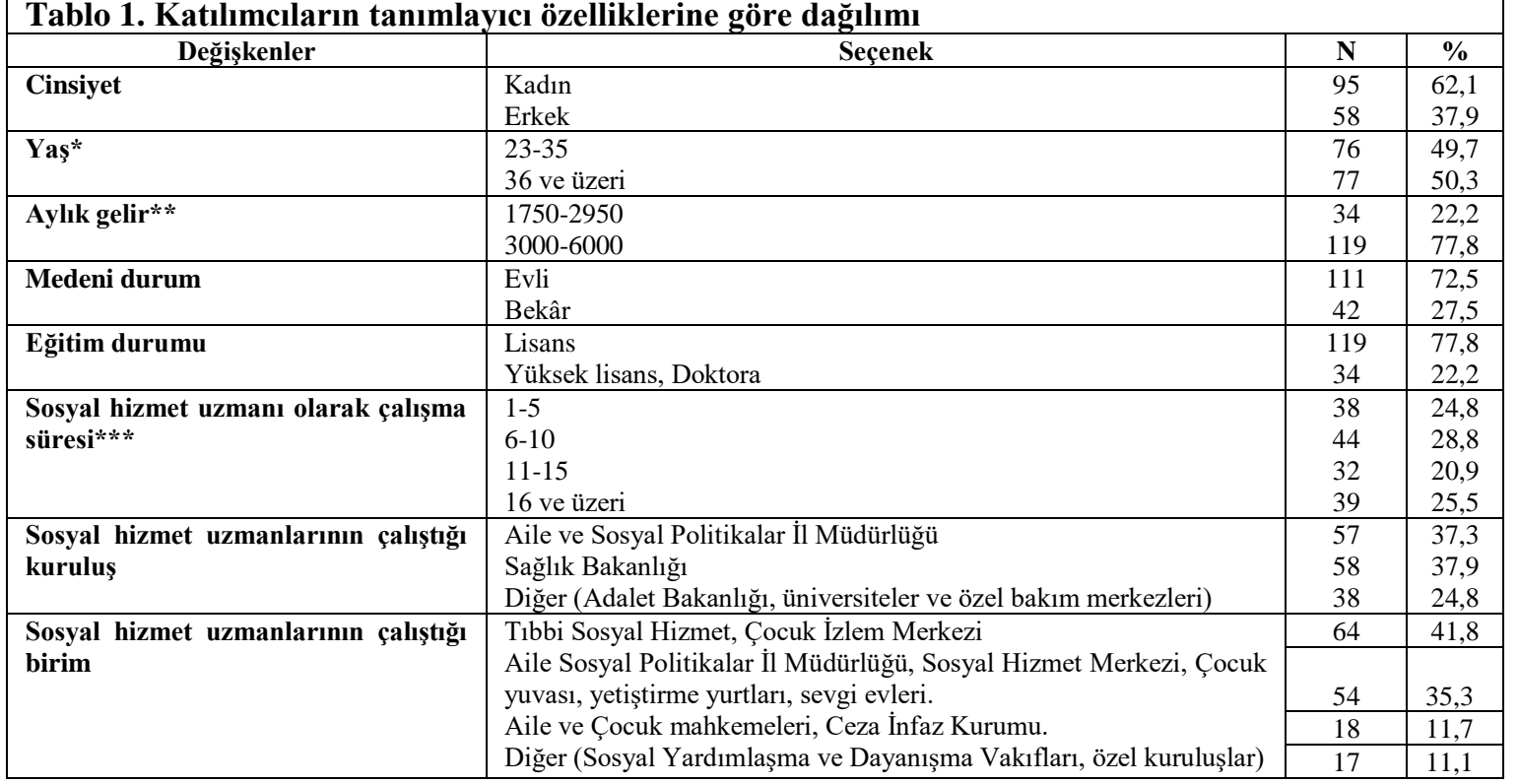

$*$ Ort $=35,59 ; \mathrm{SS}=7,69 ;$ En alt - En üst $=23-57 * *$ Ort $=3174,82 ; \mathrm{SS}=538,46 ;$ En alt - En üst $=1750-6000$

$* * *$ Ort $=11,32 ; \mathrm{SS}=7,12 ;$ En alt - En üst $=1-33$ 
Sosyal hizmet uzmanlarının çalışma süresine bakıldığında \%28,8'inin 6-10 yıldır, $\% 24,8$ 'inin 1-5 y1l aras1, \%21,0'nin 11-15 y1l aras1, $\% 25,5$ 'inin 16 yıl ve üzeri çalıştığı anlaşılmaktadır. Sosyal hizmet uzmanlarının ortalama çalışma süresi $11,32 \pm 7,12$ y1l olup en düşük 1 , en yüksek ise 33 yıldır.

Çalıştıkları kuruluşa bakıldığında, \%37,9'unun Sağlık Bakanlığında, \%37,3'ünün Aile Sosyal Politikalar İl Müdürlüğünde, \%24,8'inin ise diğer kuruluşlarda çalıştığı anlaşılmaktadır. Diğer olarak belirtilen kuruluşlar; Adalet Bakanlığı (18 kişi), Sosyal Yardımlaşma ve Dayanışma Vakfı
(SYDV, 6 kişi), Üniversite ve özel bakım merkezleridir (14 kişi).

Sosyal hizmet uzmanlarının çalıştıkları birimler incelendiğinde, \%41,8'inin tıbbi sosyal hizmet birimi ve Çocuk İzlem Merkezlerinde, \%35,3'ünün Aile ve Sosyal Politikalar İl Müdürlüğü'ne bağlı Sosyal Hizmet Merkezleri, çocuk yuvası, yetiştirme yurtları, sevgi evleri gibi kuruluşların birimlerinde, \%11,7'sinin Aile ve Çocuk Mahkemeleri ile Ceza İnfaz Kurumlarında, \%11,1'inin ise diğer (SYDV, özel kuruluşlar) kuruluşlara ait birimlerde çalıştıkları görülmektedir.

Tablo 2: Katılımcıların gelir durumuna göre mesleki bağlılık ölçeği alt boyut puanlarının karşılaştırılması

\begin{tabular}{|c|c|c|c|c|c|c|}
\hline Bağımlı değişken & Gelir & $\mathbf{N}$ & $\bar{X}$ & SS & $\mathbf{t}$ & p \\
\hline \multirow{2}{*}{ Duygusal Mesleki Bağlılık } & $\geq 3000$ & 119 & 27,04 & 6,66 & \multirow{2}{*}{$-2,979$} & \multirow{2}{*}{, $004 *$} \\
\hline & $<3000$ & 34 & 30,88 & 6,61 & & \\
\hline \multirow{2}{*}{ Mesleki Devamlılık Bağlılığı } & $\geq 3000$ & 119 & 25,85 & 7,29 & \multirow{2}{*}{$-3,275$} & \multirow{2}{*}{, $002 *$} \\
\hline & $<3000$ & 34 & 29,44 & 5,05 & & \\
\hline \multirow{2}{*}{ Normatif Mesleki Bağlılık } & $\geq 3000$ & 119 & 22,89 & 7,80 & \multirow{2}{*}{, 011} & \multirow[t]{2}{*}{,991 } \\
\hline & $<3000$ & 34 & 22,88 & 7,86 & & \\
\hline
\end{tabular}

Tablo 2 incelendiğinde mesleki bağlılık ölçeği puanlarına bakıldığında, duygusal mesleki bağlılık ve mesleki devamlılık bağlılı̆̆ alt boyutunda geliri 3000 ve üzeri olan katılımcıların puan1, geliri 3000 TL'nin altında olan katılımcılardan yükssek çıkmıştır.

Yapılan istatistiksel analizler sonucunda, sosyal hizmet uzmanlarının gelirleri ile mesleki bağlılık ölçeğinin duygusal mesleki bağlılık ve mesleki devamlılık bağlılığ 1 alt boyutunda anlamlı farklılık bulunmuştur $(\mathrm{p}<0,05)$. Buna göre geliri 3000 'in altında olan sosyal hizmet uzmanlarının duygusal mesleki bağlılığı (Ort=27,04) ve mesleki devamlılık bağlılığ $($ Ort=25,85) daha düşüktür. Bir başka deyişle aylık gelir arttıkça duygusal mesleki bağlılık alt boyutu ve mesleki devamlılık bağlılığ alt boyutu artmaktadır.

Tablo 3: Katılımcıların çalıştıkları kuruluşa göre mesleki bağlılık ölçeği alt boyut puanlarının karşılaştırılmasıı

\begin{tabular}{|c|c|c|c|c|c|c|c|c|c|c|}
\hline Bağımlı Değiş̧ken & $\begin{array}{l}\text { Çalıştı̆̆ı } \\
\text { kuruluş }\end{array}$ & $\mathbf{N}$ & $\overline{\mathbf{X}}$ & SS & Varyans kaynağı & KT & Sd & KO & $\mathbf{F}$ & $\begin{array}{c}\text { Anlamlıllk } \\
\text { düzeyi }\end{array}$ \\
\hline \multirow{3}{*}{$\begin{array}{c}\text { Duygusal Mesleki } \\
\text { Bağl1lık }\end{array}$} & ASPİM & 57 & 27,50 & 6,39 & Gruplar arasında & 161,373 & 2 & 80,687 & \multirow{3}{*}{1,750} & \multirow{3}{*}{, 177} \\
\hline & $\begin{array}{c}\text { Sağlık } \\
\text { Bakanlığ } 1 \\
\end{array}$ & 58 & 27,12 & 6,24 & Gruplar içinde & 6914,953 & 150 & 46,100 & & \\
\hline & Diğer & 38 & 29,65 & 8,05 & Toplam & 7076,327 & 152 & & & \\
\hline \multirow{3}{*}{$\begin{array}{l}\text { Mesleki Devamlılık } \\
\text { Bağlılığı }\end{array}$} & ASPIM & 57 & 27,29 & 5,71 & Gruplar arasında & 533,723 & 2 & 266,862 & \multirow{3}{*}{5,780} & \multirow{3}{*}{, $004 *$} \\
\hline & $\begin{array}{c}\text { Sağlık } \\
\text { Bakanlığı }\end{array}$ & 58 & 24,43 & 7,11 & Gruplar içinde & 6924,917 & 150 & 46,166 & & \\
\hline & Diğer & 38 & 29,07 & 7,72 & Toplam & 7458,641 & 152 & & & \\
\hline \multirow{3}{*}{$\begin{array}{l}\text { Normatif Mesleki } \\
\text { Bağlll1k }\end{array}$} & ASPIM & 57 & 22,66 & 6,89 & Gruplar arasında & 217,042 & 2 & 108,521 & \multirow{3}{*}{1,807} & \multirow{3}{*}{, 168} \\
\hline & $\begin{array}{c}\text { Sağlık } \\
\text { Bakanlığı }\end{array}$ & 58 & 21,82 & 7,62 & Gruplar içinde & 9007,285 & 150 & 60,049 & & \\
\hline & Diğer & 38 & 24,86 & 9,04 & Toplam & 9224,327 & 152 & & & \\
\hline
\end{tabular}


Tablo 3'te sosyal hizmet uzmanlarının mesleki bağlılık ölçeği alt boyutlarının "ANOVA" testi sonuçlarına yer verilmiştir.

Varyans analizi sonuçlarına göre sosyal hizmet uzmanlarının duygusal mesleki bağlılık $(F=1,750, \quad p>0.05), \quad$ mesleki devamlılık bağlılığ $(\mathrm{F}=0.004, \quad \mathrm{p}<0.05)$, normatif mesleki bağlilık
$(\mathrm{F}=, 168 \mathrm{p}>0.05)^{\prime}$ 'dir. $\mathrm{Bu}$ durumda mesleki devamlılık bağlılığ 1 alt boyutunda sosyal hizmet uzmanlarının çalıştıkları kuruluş değişkenine göre anlamlı bir farklılaşma bulunmuștur. Farklılaşmanın kaynağını bulmak için Tukey Testi yapılmış ve sonuçlar tablo 4 'te verilmiştir.

\begin{tabular}{|c|c|c|c|c|c|}
\hline Bağımlı değişken & Kuruluş (I) & Kuruluş (II) & $\begin{array}{c}\text { Ortalamalar } \\
\text { arası fark }\end{array}$ & Standart hata & $\mathbf{p}$ \\
\hline $\begin{array}{c}\text { Mesleki } \\
\text { Devamlılık } \\
\text { Bağlılığı }\end{array}$ & Sağlık Bakanlığı & Diğer & $-4,64791^{*}$ & 1,41805 &, $004 *$ \\
\hline
\end{tabular}

$* p<0.05$

Tablo 4 incelendiğinde, mesleki devamlılık bağlılığı alt boyutunda, Sağlık Bakanlığında çalışan sosyal hizmet uzmanlarının puanı diğer (Adalet Bakanlığı, SYDV, üniversite, özel bakım merkezleri) kuruluşlarda çalışanlardan düşüktür. Bir başka deyişle Sağlık Bakanlığında çalışan sosyal hizmet uzmanlarının mesleki devamlılık bağlılığı diğer kuruluşlarda çalışanlara göre daha düşüktür.

\begin{tabular}{|c|c|c|c|}
\hline & $\begin{array}{l}\text { Duygusal Mesleki Bağlılık } \\
\text { Alt Boyutu }\end{array}$ & $\begin{array}{l}\text { Mesleki Devamlılık } \\
\text { Bağlılığı Alt Boyutu }\end{array}$ & $\begin{array}{l}\text { Normatif Mesleki Bağlılık } \\
\text { Alt Boyutu }\end{array}$ \\
\hline Yaş & .101 & .128 & .045 \\
\hline Gelir & .263 & $.152 * *$ & .022 \\
\hline Çalışma & .095 & .071 & .053 \\
\hline
\end{tabular}

Sosyal Hizmet uzmanlarının yaş, gelir, çalışma süresi bağımsız değişkenleri ile mesleki bağlılık alt boyutları arasındaki ilişkinin analizi Pearson Momentler Çarpım korelasyon katsayısı tekniği ile sınanmış sonuçlar Tablo 5'te verilmiştir.
Tablo 5 incelendiğinde sosyal hizmet uzmanlarının gelir düzeyi ile mesleki devamlılık bağl1lı̆̆1 alt boyutunda pozitif yönlü anlamlı bir ilişki bulunmuştur $(r=0.152)$. Yani Sosyal Hizmet uzmanlarının gelir seviyeleri arttıkça mesleki devamlılık bağlılığı alt boyutu da artmaktadır. Yaş, gelir, çalışma süresi bağımsız değişkenlerinin duygusal mesleki bağlılık ve normatif mesleki bağlılık alt boyutu ile anlamlı bir ilişki bulunmamıştır.

Araştırma kapsamında sosyal hizmet uzmanlarının cinsiyet, yaş, çalışma süresi gibi değişkenlerin mesleki bağlılık ölçeğinin alt boyutları ile ilişkili olup olmadığg incelenmiş ve bu değişkenler açısından mesleki bağlılık puanları arasında anlamlı düzeyde farklılaşma saptanmamıştır. Buna göre sosyal hizmet uzmanlarının cinsiyet değişkenine göre "mesleki bağlılık ölçeği” puanları arasında anlamlı farklılık olup olmadığı t testi ile sınanmış ve yapılan istatistiksel analizler sonucunda, kadın sosyal hizmet uzmanları ile erkek sosyal hizmet uzmanlarının mesleki bağlılık puanları arasında anlamlı düzeyde farklılaşma saptanmamıştır $(\mathrm{p}>0,05)$. Sosyal hizmet uzmanlarının yaş değişkenine göre "mesleki bağl1lık ölçeği" puanları arasında anlamlı farklılık olup olmadığı t testi ile sınanmış ve yapılan istatistiksel analizler sonucunda, 35 yaş altı olan sosyal hizmet uzmanları ile 35 yaş ve üzeri olan sosyal hizmet uzmanlarının mesleki bağlılık puanları arasında anlamlı düzeyde farklılaşma saptanmamıştır ( $p>0,05)$. Sosyal hizmet uzmanlarının medeni durum değişkenine göre "mesleki bağlılık ölçeği” puanları arasında anlamlı farklılık olup olmadığı t testi ile sınanmış ve yapılan istatistiksel analizler sonucunda, bekâr sosyal hizmet uzmanları ile evli sosyal hizmet uzmanlarının mesleki bağlılık puanları arasında 
anlamlı düzeyde farklılaşma saptanmamıştır $(\mathrm{p}>0,05)$.

\section{TARTIŞMA}

$\mathrm{Bu}$ araştırmanın amacı sosyal hizmet uzmanlarının mesleki bağlılıklarını bazı değişkenler açısından incelemektir. Yapılan analizler sonucu sosyal hizmet uzmanlarının mesleki bağlılıklarının cinsiyet, yaş, medeni durum, eğitim durumu, çalıştıkları hizmet yılı değişkenleri açısından istatistiksel olarak anlamlı bir ilişki bulunmamıştır. Literatürde yapılan benzer çalışmalara bakıldığında incelenen değişkenler açısından benzer ve farklı sonuçlara ulaşıldığı görülmektedir. Cihangiroğlu ve arkadaşlarının hemşireler ile yaptıkları çalışmada hemşirelerin medeni durumları ile mesleki bağlılıkları arasında istatistiksel olarak anlamlı bir ilişki bulunmamıştır. ${ }^{24}$ Yine aynı çalışmada yaş değişkeni açısından ise anlamlı sonuçlara ulaşılmıştır. Buna göre 41 yaş ve üzeri yaş grubundaki hemşirelerin duygusal bağl1lıkları ile toplam örgütsel bağlilıkları ve mesleki bağl1lıklarının diğer yaş grubundaki hemşirelerden istatistiksel olarak anlamlı düzeyde yüksek olduğu görülmüştür. ${ }^{24}$

Sağsan ve Fırtına tarafindan profesyonel olmayan kütüphanecilerle yapılan çalışmada kişinin yaşı ile mesleğe yönelik duygusal bağlılığı arasında pozitif yönlü ve bireyin mesleğine devam bağl1lı̆̆1 arasında güçlü düzeyde pozitif yönlü anlamlılık bulunmuştur. $^{21}$

Bu çalışmada incelenen bir başka değişken çalışma süresidir. Yapılan çalışmada sosyal hizmet uzmanlarının çalıştıkları süre ile mesleki bağlılık ölçeği alt boyutları arasında anlamlı bir ilişki yoktur. Oysaki literatür incelendiğinde genellikle çalışma süresi ile mesleki ya da örgütsel bağlılık arasında anlamlı ilişkilerin bulunduğu çalışmalar göze çarpmaktadır. Hemşirelerle yapılmış bir çalışmada hizmet süresi 21 yıl ve üzeri olan hemşirelerin örgütsel bağlılıkları ve mesleki bağl1lıklarının, diğer hizmet sürelerindeki hemşirelere göre istatistiksel olarak anlamlı düzeyde yüksek olduğu bulunmuştur. ${ }^{24}$ Benzer şekilde Sağsan ve Fırtına tarafindan yapılan çalışmada da kişinin mesleğindeki kıdemi ile mesleğine karşı hissettiği devam bağlılığı arasında pozitif yönlü anlamlı ilişki bulunmuştur. ${ }^{17}$ Buna benzer şekilde bir başka çalışma Arslantürk tarafindan ikinci bir işte çalışma durumunun mesleki bağl1lığa etkisi üzerinedir. ${ }^{22}$ Buna göre turist rehberlerinin ikinci işte çalışma durumuna göre mesleki bağl1lık boyutlarından duygusal ve devamlılık bağlılığ olarak anlamlı bir fark bulunmuştur. ${ }^{22}$ Bir başka ifadeyle ikinci işte çalışmayanların çalışanlara göre duygusal ve devam bağlılıkları ortalamaları daha yüksek bulunmuştur.

Çalışma süresinin mesleki bağlılığa olan etkisi sosyal hizmet alanında yapılan çalışmalarla ele alındığında, çalışılan sürenin mesleki bağlılık geliştirme konusunda etkili olduğu birtakım çalışmalar olduğu görülmektedir. Evans ve Huxley tarafindan Galler'de 1000 sosyal hizmet uzmanı ile yapılan çalışmada ortalama on yıl tecrübeli katılımcıların mesleklerinin birçok özelliğini sevdiği, katılımcıların neredeyse tamamına yakınının hizmetten yararlananları sevdiği, yine tamamına yakınının ekip çalışmasını sevdiği ortaya çıkmış, tüm bu özelliklerin yüksek mesleki bağlılık içerdiği gözlenmiştir. ${ }^{25}$ Yine McLean ve Andrew'in 1000 sosyal hizmet uzmanı ve idareciler ile İngiltere'de yaptığı çalışmada, hizmetin uzunluğunun, idareci rolü üstlenmenin organizasyona bağlılıkta önemli olduğu, ayrıca çalışanların kuruma bağlılığı ve uzun hizmet süreleri arasında bir ortaklığın olduğu görülmüştür. $\mathrm{Bu}$ nedenle uzun süreli çalışan ve kuruma daha çok zaman ve enerji harcayan çalışanların kuruma diğer çalışanlardan daha çok özdeşleştikleri görülmüştür. ${ }^{26}$

Bu çalışmada sosyal hizmet uzmanlarının eğitim durumları ile mesleki bağlılık ölçeği alt boyutları arasında anlamlı bir ilişki bulunmadığı sonucuna ulaşılmıştır. Bu durumun eğitim durumu açısından verilerin çok homojen bir gruptan oluştuğundan kaynaklandığı düşünülmektedir. Sosyal hizmet uzmanı unvanına sahip olmak için en az lisans mezunu olmak gerektiği düşünüldüğünde, eğitim durumundaki farklılaşmanın lisansüstü eğitimi kapsadığı görülmektedir. Sosyal hizmet alanında ülkemizdeki lisansüstü eğitimin çok uzun yıllar tek bir üniversitede verilmesi, günümüzde ise sınırlı sayıda üniversitede bu alanda eğitim veren lisansüstü programların bulunması nedeniyle bu eğitim firsatına erişim konusunda sosyal hizmet uzmanlarının çok avantajlı bir konumda olmadıkları ve çalışmaya dâhil edilen sosyal hizmet uzmanlarının eğitim durumlarına ilişkin çok yüksek oranda bir çeşitlilik göstermediği anlaşılmaktadır. Literatürde ise mesleki bağlılı̆̆ın eğitim ile birlikte gelişmeye başladığı vurgulanmaktadır. Sosyal hizmette mesleki bağlılığın yine sosyal hizmet kariyerinin ilk yıllarında ya da eğitim ve staj döneminde geliştiği düşünülmektedir. İsrail'de sosyal hizmet eğitimine yeni başlayan 450 sosyal hizmet öğrencisi ile yapılan çalışmada sosyal hizmet mesleğine bağlılığın yüksek olduğu görülmüştür. ${ }^{27} \mathrm{Bu}$ çalışmada, sosyal değişimi görme arzusu ve mesleki bağlılık arasında pozitif yönlü bir ilişki bulunmuştur. Mesleki eğitim sürecinin önemli bir parçası olan süpervizyon da mesleki bağlılığın gelişmesinde rol oynayan önemli aktörlerden biridir. Sosyal hizmet uzmanlarıla 
gerçekleştirilen bir başka çalışmada daha az deneyimli çalışanların daha yüksek duygusal yıpranma yaşadıkları ve depresyon hislerinin ek süpervizörlük hizmetleriyle desteklenmesinin önemli bir gereklilik olduğu vurgulanmıştır. ${ }^{28}$ Bir başka çalışma ise Clements, Kinman ve Gruppy tarafından yapılmış nitel bir çalışmadır. $\mathrm{Bu}$ çalışmayı yazarlar İngiltere'de üç sosyal hizmet akademisyeni ve yedi sosyal hizmet öğrencisi ile gerçekleştirmiştir. ${ }^{29} \mathrm{Bu}$ çalışmada da katılımcıların mesleki bağlılığının yüksek olduğu gözlenmiştir. $\mathrm{Bu}$ da sosyal hizmet uzmanları tarafindan sosyal hizmet programının taleplerle başa çıkabilmesi ve sıkı ilişkiler kurabilmesinin gerekliliği bağlamında mesleki değerlere adanmışlık olarak tanımlanmıştır.

$\mathrm{Bu}$ çalışmada incelenen bir başka değişken gelir durumudur. Sosyal hizmet uzmanlarının gelir durumu incelendiğinde, sosyal hizmet uzmanlarının gelirleri ile mesleki bağlılık ölçeğinin duygusal mesleki bağlılık ve mesleki devamlılık bağlılığı alt boyutunda anlamlı farklılık olduğu görülmüştür. Buna göre geliri 3000'in altında olan sosyal hizmet uzmanlarının duygusal mesleki bağlılığ ve mesleki devamlılık bağlılığı daha düşüktür. Bir başka deyişle aylık gelir arttıkça duygusal mesleki bağlılık alt boyutu ve mesleki devamlılık bağlılı̆̆1 alt boyutu artmaktadır. Yapılan korelasyon analizinde de sosyal hizmet uzmanlarının gelir düzeyi ile mesleki devamlılık bağlılığ alt boyutunda pozitif yönlü anlamlı bir ilişki bulunmuştur. Yani sosyal hizmet uzmanlarının gelir seviyeleri arttıkça mesleki devamlılık bağlılığı alt boyutu da artmaktadır. Duygusal bağlılık daha önce tanımlandığı gibi çalışanların kendilerini çalıştıkları kuruma ne kadar özdeşleştirdikleri ile ilgili duyguları ve bireylerin çalıştıkları işyerine olan ilgilerini göstermektedir. Devamlılık bağlılığı ise bireylerin çalıştıkları işyerlerinden ayrılmaları halinde ortaya çıkabilecek olan maliyetlerin farkındalıkları ile ilgilidir. Bir başka ifadeyle, birey birtakım zorunluluklar nedeniyle mesleğinde kalmaya devam etmektedir. ${ }^{5}$ Buna göre geliri düşük olan sosyal hizmet uzmanlarının duygusal mesleki bağlılığının düşük olması bu bireylerin meslekte kalmayı güçlü bir şekilde arzu etmediklerini göstermektedir. Aynı zamanda mesleki devamlılık bağlılığının da düşük olması bu bireylerin birtakım zorunluluklar nedeniyle mesleğinde kalmaya devam ettiklerini göstermesi açısından önemlidir.

Literatürde duygusal bağlılığın mesleği bırakma niyeti üzerinde olumsuz bir etkisi olduğuna ilişkin çalışmalar bulunmaktadır. ${ }^{30}$ Nitekim Tak ve arkadaşlarının hekimler ile yaptığı çalışmada, hekimlerin mesleki bağlılıkları ile meslekten ve örgütten ayrılma niyeti arasındaki ilişkiler incelenmiş, bunun sonucunda sadece duygusal mesleki bağlilığın meslekten ayrılma niyeti üzerinde doğrudan ve negatif yönlü bir etkiye sahip olduğu sonucuna ulaşılmıştır. $\mathrm{Bu}$ durum araştırmacılar tarafından mesleğine duygusal olarak bağlı hekimlerin mesleklerinden ayrılma niyeti içinde olmadıkları şeklinde yorumlanmıştır. ${ }^{20}$ Yine buna benzer bir başka çalışma birinci basamakta çalışan aile hekimlerinin kurumlarına olan destek algılarını ortaya koyabilmek amacıyla yapılmış ve aile hekimlerinin örgütsel destek algılarının örgütsel özdeşleşme ve işten ayrılma niyeti üzerine etkisi araştırılmıştır. ${ }^{31}$ Buna göre aile hekimlerinin kurumlarında çalıştıkları süre arttıkça örgütsel destek algılarının azaldığ 1 algılanan örgütsel destek ile örgütsel özdeşleşme arasında pozitif yönlü ve anlamlı ilişki bulunduğu sonucuna varılmıștır. Buna göre aile hekimlerinin algılanan örgütsel düzeyi arttıkça örgütsel özdeşleşmeleri de artmaktadır. Bunun yanında aile hekimlerinin örgütsel destek düzeyi arttıkça işten ayrılma niyeti de azalmaktadır. $^{31}$

Sosyal hizmet uzmanlarının çalıştıkları kuruluş değişkeni açısından mesleki devamlılık bağlılı̆̆ 1 alt boyutunda anlamlı bir farklılaşma bulunmuştur. Buna göre Sağlık Bakanlığında çalışan sosyal hizmet uzmanlarının puanının diğer (Adalet Bakanlığı, SYDV, üniversite, özel bakım merkezleri) kuruluşlarda çalışanlardan düşük olduğu görülmüştür. Bir başka deyişle, Sağllk Bakanlığında çalışan sosyal hizmet uzmanlarının mesleki devamlılık bağlılığı diğer kuruluşlarda çalışanlara göre daha düşüktür. Sağlık Bakanlığı ile diğer kurumlar, özellikle de Aile ve Sosyal Politikalar Bakanlığı, SYDV gibi kurumlar hizmet verme öncelikleri açısından değerlendirildiğinde Sağlık Bakanlığına bağlı kurumların birincil amacının sosyal hizmetten ziyade teşhis ve tedavi olduğu dikkat çekmektedir. $\mathrm{Bu}$ açıdan düşünüldüğünde, sosyal hizmet uzmanları tarafından verilen hizmetler ikincil, hatta üçüncül düzeyde kalmaktadır. Sağlık Bakanlığı bünyesinde çalışan sosyal hizmet uzmanlarının, diğer kurumlarda çalışanlarla kıyaslandığında, kurumda sunulan olanaklar ve kurumda değerli hissetme ve yükselme olanakları açısından daha dezavantajlı oldukları görülmektedir. Sosyal hizmet literatüründe önemli bir yere sahip olan Duyan'ın öncü çalışmaları ile üzerinde sıklıkla çalışılan tıbbi sosyal hizmet alanı, sosyal hizmetin ülkemizde ilk uygulanmaya başlandığı alan olarak önemli bir yere sahiptir. ${ }^{32}$ Ancak, bu alanda çalışan sosyal hizmet uzmanlarının mesleki bağlılıklarının diğer sosyal hizmet alanlarına kıyasla daha düşük olmasının muhtemel sebepleri incelendiğinde sosyal hizmet uzmanlarının sağlık alanındaki tanınırlığının düşük olması ile karşılaşılmaktadır. Tıbbi sosyal hizmet alanında çalışan sosyal hizmet uzmanları ile gerçekleştirilen bir çalışmada, çalışma kapsamında görüşme yapılan sosyal hizmet uzmanları tıbbi sosyal hizmet alanının geleceği ile ilgili sağlık alanındaki tanınırlığın azlığına ve mesleki 
sınırlarının net olmadığına vurgu yapılmıştır. ${ }^{33}$ Özbesler ve İçağasıŏlu Çoban tarafindan hastane ortamında çalışan sosyal hizmet uzmanları ile gerçekleştirilen bir başka çalışmada ise sosyal hizmet uzmanlarından tıbbi sosyal hizmet alanında yaşadıkları en önemli mesleki sorunları sıralamaları istenmiştir. Sosyal hizmet uzmanları bu sorunları, "mesleğin hastanede çalışan diğer personel ve yöneticiler tarafindan yeterince tanınmaması; yetki ve sorumlulukların tam olarak belli olmaması; oturmuş bir sistem olmaması; bilgi verilmesine rağmen sosyal hizmet uzmanına yönlendirme yapılmaması yani saygı duyulmaması; yasadaki görev tanımlarının sınırlı olması" şeklinde sıralamışlardır. ${ }^{34}$ Yaşanılan bu sorunların mesleki bağlılıkla ilişkisi tartışıldığında özellikle mesleğin tanınma oranının düşük olmasının ve mesleğe yeterince saygı duyulmamasının düşük mesleki bağlılı̆̆ı, özellikle de mesleki devamlılık bağlılığını açıklayıcı bir veri olarak değerlendirilebilir. Daha önce de ifade edildiği gibi mesleki devamlılık bağlılığı bireylerin çalıştıkları işyerlerinden ayrılmaları halinde ortaya çıkabilecek olan maliyetlerin farkındalıkları ile ilgilidir. Bir başka ifadeyle birey birtakım zorunluluklar nedeniyle mesleğinde kalmaya devam etmektedir. Dolayısıyla Sağlık Bakanlığı çerçevesinde çalışan uzmanların mesleğe devam isteklerinin düşük olduğu söylenebilir. Benzer şekilde bir başka çalışma çocuk koruma alanında çalışan sosyal hizmet uzmanları ile yapılmış odak grup çalışmasıdır. Amerika Birleşik Devletleri'nde çocuk koruma alanında en az sekiz yıl çalışmış olan 21 sosyal hizmet uzmanıyla yapılan odak grup çalışmasında, hizmet kullananlara bağlılığın ve profesyonel bağlılığın devam edebilme açısından gerekli olduğuna vurgu yapılmaktadır. Değerli görülme hissi, kaliteli çalışmaya verilen geribildirim, çaba, sabır ve başarı bağlılık geliştirme ve mesleği devam ettirme açısından önemli görülmüştür. ${ }^{35}$

\section{SONUÇ VE ÖNERILLER}

Sosyal hizmet uzmanlarının mesleki bağlılık düzeylerinin bazı değişkenlere göre incelenmesini amaçlayan bu çalışmanın sonuçlarına göre, sosyal hizmet uzmanlarının mesleki bağlılıklarının gelir durumu, çalıştıkları kurum değişkenine göre farklılaştığ1 görülmektedir. Cinsiyet, yaş, medeni durum, eğitim durumu, çalıştıkları hizmet yılı değişkenleri açısından ise sosyal hizmet uzmanlarının mesleki bağlılığı arasında istatistiksel olarak anlamlı bir ilişki bulunmadığı sonucuna ulaşılmıştır.

Araştırma sonucunda; sosyal hizmet uzmanlarının gelirleri ile mesleki bağlılık ölçeğinin duygusal mesleki bağlılık ve mesleki devamlılık bağlilığı alt boyutunda anlamlı farklılık bulunmuştur. Sosyal hizmet uzmanlarının aylık geliri arttıkça duygusal mesleki bağlılıkları ve mesleki devamlılık bağlılığı artmaktadır. $\mathrm{Bu}$ bağlamda sosyal hizmet uzmanlarının gelirlerini artıracak birtakım çalışmaların yapılması önerilmektedir. Özellikle sosyal hizmet mesleğinin örgütlenme sürecinin halen tamamlanmamış olmasının sosyal hizmet uzmanlarının çeşitli kuruluşlardaki maaş, ek ödeme gibi düzenlemelerin planlanması sürecinde paydaş olarak yer alamamasinın sebeplerinden biri olarak değerlendirilebilir. Bu çerçevede meslek yasasının çıkarılması ve sosyal hizmet mesleğinin örgütlenme düzeyinin dernek faaliyetlerinden meslek odas1 oluşumuna doğru değişimini sağlayacak çalışmaların hızlandırılması önerilmektedir.

Sosyal hizmet uzmanlarının çalıştıkları kuruluş değişkenine göre mesleki devamlılık bağlılığında anlamlı bir farklılaşma bulunmuştur. Buna göre araştırma kapsamındaki sosyal hizmet uzmanlarından Sağlık Bakanlığında çalışanların mesleki devamlılık bağlılığı diğer kuruluşlarda çalışanlara göre daha düşük bulunmuştur. Sağlığın ön planda olduğu bir alan olan ve sosyal hizmet uzmanlarının sağlık lisansiyerleri kapsamında görev yaptıkları bir kurum olan Sağlık Bakanlığında görev yapan yöneticiler ve müracaatçı gruplar tarafından tanınırlığını ve saygınlığını arttırıcı çalışmalara ihtiyaç duyulduğu anlaşılmaktadır. Ayrica bu alanda çalışan diğer meslek elemanlarının mesleki bağlilıklarıyla karşılaştırılabilecek verilerin toplanması için mesleki bağlılıkla ilgili çalışmaların sağlık ve sosyal hizmet alanında çalışan doktorlar, hemşireler, aile hekimleri, psikologlar, çocuk gelişim uzmanları gibi meslek gruplarını da kapsayacak şekilde çeşitlendirilmesinin mesleki aidiyeti etkileyen alana özgü özelliklerin belirlenmesi açısından faydalı olacağ düşünülmektedir.

$\mathrm{Bu}$ araştırmada elde edilen bulgular çalışma kapsamındaki sosyal hizmet uzmanlarından elde edilen verilerle sinırlıdır. Dolayısıyla genelleme yapmak açısından oldukça sınırlı verilerle çalışılmıştır. Daha geniş uzman popülasyonlarıyla benzer çalışmaların yapılması önerilmektedir.

\section{KAYNAKLAR}

1. Meyer J, Herscovitch L. Commitment in the workplace: Toward a genaral model. Human Resourch Management Review, 2001, 11: 299326.

2. Greenhouse JH. An investigation of role of career salience in vocational behavior. Journal of Vocational Behavior, 1971, 1: 209-16. 
3. Blau G. The measurement and prediction of career commitment. Journal of Occupational Psychology, 1985, 58:277-88.

4. Aranya N, Ferris KR. A reexamination of accountants organizational-professional conflict. The Accounting Review, 1984, 59: 115 .

5. Meyer JP, Allen NJ, Simith CA. Commitment to organizations and occupations: Extension and test of a three-component conceptualization. Journal of Applied Psychology, 1993, 78, 538-51.

6. Meyer J, Allen N. A three-component reconceptualization of organizational commitment. Human Resource Management Review, 1991, 1 (1): 61-89.

7. Lanchman R, Aranya N. Evaluation of alternative models of commitmrnt and job attitudes of professionals. Journal of Occupational Behavior, 1986, 7: 227-43.

8. Duyan V. Sosyal Hizmet Temelleri Yaklaşımları Müdahale Yöntemleri. Ankara, Sosyal Çalışma Yayınları, 2014. p. 8-14.

9. Tufan B, Sayar ÖÖ, Koçyıldırım G. Sosyal bir hak olarak sosyal hizmet, Uluslararası Sosyal Haklar Sempozyumu 22-23 Ekim 2009, Antalya, Akdeniz Üniversitesi. 2009. p. 76-86.

10. Collins S. The commitment of social workers in the UK: Committed to the profession, the organisation and service users? Practice: Social Work in Action, 2016, 28:3, 159-79, DOI:10.1080/09503153.2015.1074668.

11. Gifford E. An examination of organizational commitment and professional commitment and the relationship to work environment: Demographic and organizational factors. Journal of Social Work, 2009, 9(4): 386-404.

12. Banks S. Integrity in Professional life: Issues of conduct, commitment and capacity. British Journal of Social Work, 2010, 40(7): 2168-84.

13. Karasar N. Bilimsel Araştırma Yöntemi. Ankara, Nobel Yayın Dağıtım, 2006.

14. Krysik J.L, Finn J. Etkili Uygulama İçin Sosyal Hizmet Araştırması. Çev.Edit. Ercüment Erbay, Nika Yayınevi, 2015.p.273.

15. Tak B, Çiftçioğlu Aydemir B. Üç boyutlu mesleki bağlılık ölçeğinin Türkçe'de güvenirlik ve geçerliğinin incelenmesine yönelik bir alan araştırması. İşletme Fakültesi Dergisi, 2009, 10(1): 35-54.

16. Baysal AC, Paksoy M. Mesleğe ve örgüte bağlılığın çok yönlü incelenmesinde MeyerAllen Modeli. İ.Ü. İşletme Fakültesi Dergisi, 1999, 28(1):7-15.

17. Snape E, Redman T. An evaluation of a threecomponent model of occupational commitment: Dimensionality and consequences among United Kingdom human resources specialists. Journal of Applied Psychology, 2003, 88(1):152-9.
18. Irving PG, Coleman DF, Cooper CL. Further assessments of a three-component model of occupational commitment: Generalizability and differences across occupations. Journal of Applied Psychology, 1997, 82(3): 444-52.

19. Blau G. Testing for a four-dimensional structure of occupational commitment. Journal of Occupational and Organizational Psychology, 2003, 76(4): 469-88.

20. Tak B, Çiftçioğlu AB, Özçakır A, Divleli A. Mesleki bağlılığın bireylerin mesleklerine ve çalıştıkları örgüte ilişkin tutumlarını nasıl etkilediğini anlamaya yönelik bir alan araştırması. "İş, Güç" Endüstri İlişkileri ve İnsan Kaynakları Dergisi, 2009, 11(3):89-102. DOI:10.4026/1303-2860.2009.0120.X.

21. Sağsan M, Fırtına B. Bilgi mesleğine bağlılık ve adanmışlık: Platonik bir ilişkinin gelgitleri ve profesyonellikle imtihanı. Bilgi Dünyası, 2015, 16(1):1-22.

22. Arslantürk Y. Mesleki bağlılık: Turist rehberleri üzerine bir inceleme. İşletme Araştırmaları Dergisi, 2016, 8(1):186-207.

23. Özdamar K. Paket Programlar İle İstatistiksel Veri Analizi 1. Eskişehir, Kaan Kitabevi, 1999.

24. Cihangiroğlu N, Teke A, Özata M, Çelen Ö. Mesleki bağlılık ile örgütsel bağlılık arasındaki ilişkinin analizi. Gülhane Tıp Dergisi, 2015, 57: 367-72.

25. Evans S, Huxley P. Factors associated with the recruitment and retention of social workers in Wales: Employer and employee perspectives. Health and Social Care in the Community, 2009, 17(3): 254-66.

26. McLean J, Andrew T. Commitment, satisfaction, stress and control among social service managers and social workers in the UK. Administration in Social Work, 2000, 22(3-4): 93-117.

27. Freund A, Blit-Cohen E, Cohen A, Dehan N. Professional commitment in novice social work student: Socio demographic characteristics, motives and perceptions of the profession. Social Work Education, 2012, 32(7): 239-53.

28. Dickinson N, Perry R. Factors influencing the retention of specially educated public child welfare workers. Evaluation Research in Child Welfare, 2002, 15(3-4):89-103.

29. Clements A, Kinman G, Guppy A. You should damage someone's life: Student and lecturer perspectives on commitment. Social Work Education, 2013, 33(1):91-104.

30. Blau G, Holladay EB. Testing the discriminant validity of a four-dimensional occupational commitment measure. Journal of Occupational and Organizational Psychology, 2006, 79(4):691-704.

31. Find1k M. Algılanan Örgütsel Desteğin, Örgütsel Özdeşleşme ve İşten Ayrılma Niyetine Etkisi Araştırması Konya İli Aile 
Hekimleri Örneği. Yayınlanmamış Yüksek Lisans Tezi, Konya, Selçuk Üniversitesi Sosyal Bilimler Enstitüsü İşletme Anabilim Dalı Yönetim Organizasyon Bilim Dalı, 2011.

32. Duyan V. Sağlıkta Psiko-Sosyal Boyut (Tıbbi Sosyal Hizmet). Ankara, 72TFDO, 1996.

33. Yanardağ U. Tıbbi sosyal hizmet uzmanlarının gözünden tıbbi sosyal hizmet alanı. İçinde: Attepe Özden S, Özcan E, editör, Tibbi Sosyal Hizmet. 1. Baskı. Ankara, Nobel Yayınevi, 2017, s.91-6.
34. Özbesler C, İçağasığlu Çoban A. Hastane ortamlarında sosyal hizmet uygulamaları: Ankara Örneği. Toplum ve Sosyal Hizmet, 2010, 21(2):31-46.

35. Westbrook $\mathrm{T}$, Ellis $\mathrm{J}$, Ellett A. Improving retention among public child welfare workers: What can we learn from the experience of committed survivors? Administration in Social Work, $\quad 2006, \quad 30 \quad$ (4):37-62. 